\title{
The Influence of Anions on the Polarographic Reduction of Aquopentamminecobalt(III) and Aquopentammine- chromium(III) Ions
}

\author{
Nobuyuki Tanaka, Yuichi Sato and Reita Tamamushi* \\ Department of Chemistry, Faculty of Science, Tohoku University, Sendai, Japan
}

(Received July 10, 1964)

\section{Synopsis}

The influence of halide and isothiocyanate ions of the reduction wave of aquopentamminecobalt(III) and aquopentamminechromium(III) ions at the dropping mercury electrode has been studied by the measurements of current-potential and current-time curves. The cobalt(III) complex ion gives a kinetic-controlled reduction wave at more positive potentials than that of the reduction of cobalt(III) to cobalt(II) in the presence of bromide, chloride, and isothiocyanate ions, but does not give in the presence of iodide ions. In the case of the chromium(III) complex ion, such a kinetic current is not observed in the presence of these anions. An interpretation of the phenomena is made from the point of the potential difference between the reduction of the complex ions and the oxidationrednction potential of the couple of mercury and mercurous halides.

\section{Introduction}

Pentamminecobalt(III) complex ions, $\left[\mathrm{CoY}\left(\mathrm{NH}_{3}\right)_{5}\right]^{2,3+}$, where $\mathrm{Y}$ is $\mathrm{NO}_{3}^{-}, \mathrm{H}_{2} \mathrm{O}$, $\mathrm{CH}_{3} \mathrm{COO}^{-}, \mathrm{NO}_{2}^{-}$etc., give a well-developed direct current polarographic wave in an acid solution. When a small concentration of halide ions is added to the solution, a new reduction wave appears at more positive potentials. It starts at the potential of the dissolution of mercury, and its behavior resembles that of kinetic wave ${ }^{1)}$. Vlček and Kůta ${ }^{1)}$ reported that the new wave denoted prewave is kinetic in nature and is caused by the reduction of the appropriate halo complex ion, $\left[\mathrm{CoX}\left(\mathrm{NH}_{3}\right)_{5}\right]^{2+}\left(\mathrm{X}=\mathrm{Cl}^{-}, \mathrm{Br}^{-}\right.$, and $\left.\mathrm{I}^{-}\right)$, which is formed by the substitution reaction at the electrode surface,

$$
\left[\mathrm{CoY}\left(\mathrm{NH}_{3}\right)_{5}\right]^{2,3+}+\mathrm{X}^{-} \rightarrow\left[\mathrm{CoX}\left(\mathrm{NH}_{3}\right)_{5}\right]^{2+}+\mathrm{Y}^{0,1-}
$$

They stated that the rate of the reaction (1) leading to the kinetic wave would have to be at least $10^{7}$ times greater than that of the corresponding reaction in the solution, and that this reaction proceeds as a substitution reaction in the adsorbed state and is catalysed by the adsorption under the influence of the electrode field.

In the present paper the problem of whether a substitution reaction similar to that in the solution actually occurs so rapidly at the electrode surface or not is discussed polarographically. If such a type of substitution reaction occurs with cobalt(III) complexes, the same phenomenon may be observed with chromium(III) complexes, because the latter is generally more substitution-labile than the former. The polarographic behavior of aquopentamminechromium(III) ion in the presence of halide ions, therefore, has been investigated.

\footnotetext{
* Present address : The Insțitute of Physical and Chemical Research, Komagome, Bunkyo-ku, Tokyo.
} 


\section{Experimental}

Aquopentamminecobalt(III) perchlorate was prepared according to the method of Werner ${ }^{2}$ and identified by the measurement of its absorption spectra. Aquopentamminechromium(III) perchlorate was prepared and identified in the same way as given in the previous paper ${ }^{3}$. All other chemicals used were of guaranteed reagent grade.

Direct current (d.c.) polarograms were recorded with a Yanagimoto Galvarecorder Model PR-2 with an automatic potential scanner. Current-time $(i-t)$ curves were recorded by a Rikadenki ER-J 1 recorder with an RLDC-201 preamplifier. The dropping mercury electrode (DME) used had an $m$ value of $1.785 \mathrm{mg} / \mathrm{sec}$, and a drop time $t_{d}$ of $4.72 \mathrm{sec}$, when measured in $0.5 \mathrm{M}$ potassium chloride solution at $25^{\circ} \mathrm{C}$ and at open circuit at $50 \mathrm{~cm}$ of the height of mercury reservoir. A saturated calomel electrode (SCE) served as a reference electrode. All measurements were carried out at $25^{\circ} \mathrm{C}$, unless otherwise stated.

\section{Results}

D.c. polarograms of $1.0 \mathrm{~m} M$ of aquopentamminecobalt(III) ions obtained in the solution containing $0.9 \mathrm{M}$ sodium perchlorate and $0.1 \mathrm{M}$ acetate buffer in the absence and the presence of $4 \times 10^{-4} \mathrm{M}$ of sodium bromide are shown in Fig. 1; a prewave appears in the

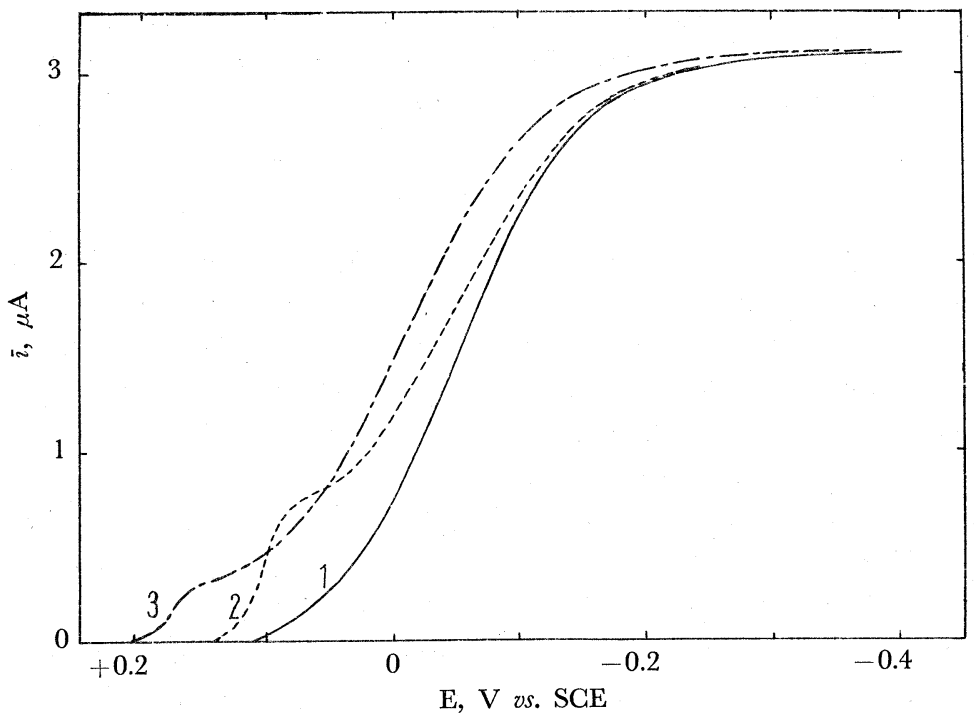

Fig. 1. Polarograms of $1.0 \mathrm{~m} M\left[\mathrm{Co}\left(\mathrm{H}_{2} \mathrm{O}\right)\left(\mathrm{NH}_{3}\right)_{5}\right]\left(\mathrm{ClO}_{4}\right)_{3}$ obtained in the solutions containing $0.9 M \mathrm{NaClO}_{4}$ and $0.1 M$ acetate buffer without (1) and with $4 \times 10^{-4} M \mathrm{NaBr}(2)$ and $5 \times 10^{-4} M \mathrm{KSCN}$ (3). The current is corrected for the residual current which is recorded with the solution of the same composition except the complex.

presence of sodium bromide. As given in Table 1 , the limiting current $\left(\bar{t}_{l}\right)$ at $-0.4 \mathrm{~V}$ is proportional to the square root of the effective height of the mercury reservoir, whereas the current of the prewave $\bar{t}_{k}$ at $+0.06 \mathrm{~V}$ is constant irrespective of the height, after it is corrected for the residual current which is obtained with the solution of the same components but no complex ions present. The values of $\bar{i}_{l}$ and $\bar{i}_{k}$ are proportional to the con- 
Table 1. Relations between the Current and the Height of the Mercury Reservoir.*

\begin{tabular}{c|c|c|c}
\hline $\begin{array}{c}h_{\text {corr }} \\
\mathrm{cm}\end{array}$ & $\begin{array}{c}\bar{i}_{k} \\
\mu \mathrm{A}\end{array}$ & $\begin{array}{c}\bar{i}_{l} \\
\mu \mathrm{A}\end{array}$ & $\ddot{i}_{l} / \sqrt{h_{\text {corr }}}$ \\
\hline 38.41 & 0.76 & 2.74 & 0.441 \\
48.41 & 0.76 & 3.06 & 0.440 \\
58.41 & 0.76 & 3.37 & 0.441 \\
68.41 & 0.67 & 3.66 & 0.442 \\
\hline
\end{tabular}

* The polarograms were obtained in the solutions containing 1.0 $\mathrm{m} M\left[\mathrm{Co}\left(\mathrm{H}_{2} \mathrm{O}\right)\left(\mathrm{NH}_{3}\right)_{5}\right]\left(\mathrm{ClO}_{4}\right)_{3}, \quad 0.9$ $M \mathrm{NaClO}_{4}, 0.1 M$ acetate buffer and $4 \times 10^{-4} M \mathrm{NaBr}$. See text for $\bar{\imath}_{k}$ and $\bar{\imath}_{l}$. centration of the complex ions as shown in Table 2. The value of $\bar{i}_{k}$ increases with increasing concentration of the bromide ion but not linearly (see Table 3 ). Polarograms were also measured at various temperatures from 0.8 to $35^{\circ} \mathrm{C}$, and the values of activation energy for the process controlling the limiting current and for the process controlling the current of the prewave were calculated ${ }^{4}$ to be $5.3 \mathrm{kcal} / \mathrm{mol}$. and approximately $16 \mathrm{kcal} / \mathrm{mol}$., respectively. From these results the limiting current is considered to be diffusion-controlled, but the prewave, to be kinetic in nature.

Fig. 2 shows a polarogram of bromopentamminecobalt(III) ions and that of aquopentamminecobalt(III) ions in the presence of $4 \times 10^{-4} M$ of sodi-

Table 2. Relations between the Current and the Concentration of the Complex Ion.*

\begin{tabular}{|c|c|c|c|c|}
\hline $\begin{array}{l}\text { Complex ion, } \\
M \times 10^{3}(C)\end{array}$ & $\begin{array}{l}\bar{i}_{k} \\
\mu \mathrm{A}\end{array}$ & $\begin{array}{c}\bar{i}_{k} / G \\
(\mu \mathrm{A} / M) \times 10^{-3}\end{array}$ & $\begin{array}{c}\bar{i}_{l} \\
\mu \mathrm{A}\end{array}$ & $\begin{array}{c}\bar{l}_{l} / G \\
(\mu \mathrm{A} / M) \times 10^{-3}\end{array}$ \\
\hline 0.4 & 0.32 & 0.81 & 1.21 & 3.04 \\
\hline 0.8 & 0.66 & 0.82 & 2.43 & 3.04 \\
\hline 1.0 & 0.81 & 0.81 & 3.04 & 3.04 \\
\hline 1.4 & 1.07 & 0.77 & 4.21 & 3.00 \\
\hline
\end{tabular}

* The polarograms were obtained in the solutions containing $0.9 M \mathrm{NaClO}_{4}, 0.1 M$ acetate buffer and $4 \times 10^{-4} M \mathrm{NaBr}$.

Table 3. Effects of the Concentration of Bromide Ions on the Height of the Prewave.*

\begin{tabular}{c|c|c}
\hline $\begin{array}{c}\mathrm{NaBr}(C) \\
M \times 10^{4}\end{array}$ & $\begin{array}{c}\bar{i}_{k_{k}} \\
\mu \mathrm{A}\end{array}$ & $\begin{array}{c}\bar{i}_{k} / C \\
(\mu \mathrm{A} / M) \times 10^{-3}\end{array}$ \\
\hline 2 & 0.48 & 2.40 \\
4 & 0.76 & 1.90 \\
8 & 1.58 & 1.95 \\
12 & 1.87 & 1.56 \\
\hline
\end{tabular}

* The polarograms were obtained in the solutions containing 1.0 $M \mathrm{NaClO}_{4}, 0.1 M$ acetate buffer and $\mathrm{NaBr}$. $\mathrm{m} M\left[\mathrm{Co}\left(\mathrm{H}_{2} \mathrm{O}\right)\left(\mathrm{NH}_{3}\right)_{5}\right]\left(\mathrm{ClO}_{4}\right)_{3}, 0.9$

um bromide. Both waves start at the dissolution of mercury, and the potential of the aquopentamminecobalt(III) wave changes with the concentration of added bromide ions. Therefore it is difficult to conclude from the reduction potential that the prewave is a reduction wave of bromopentamminecobalt(III) ion formed at the electrode surface by substitution reaction according to the Eq. (1). When surface active substances are added to the solution, the prewave is depressed, and the total reduction wave shifts to more negative potentials (Fig. 3).

Besides bromide ions, isothiocyanate (see curve 3 in Fig. 1) and chloride ions also give prewaves. The concentration of the anion necessary for the development of the prewave of a given height depends on the nature of the anion. Isothiocyanate ions have a smaller effect than bromide ions, and chloride ions a much smaller effect.

In the case of iodide ions, the prewave does not appear, but a continuous reduction wave which starts at the potential of the dissolution of mercury appears, as shown in Fig. 4. Curve 3 which was obtained by subtraction of the anodic iodide wave (curve 2) from 


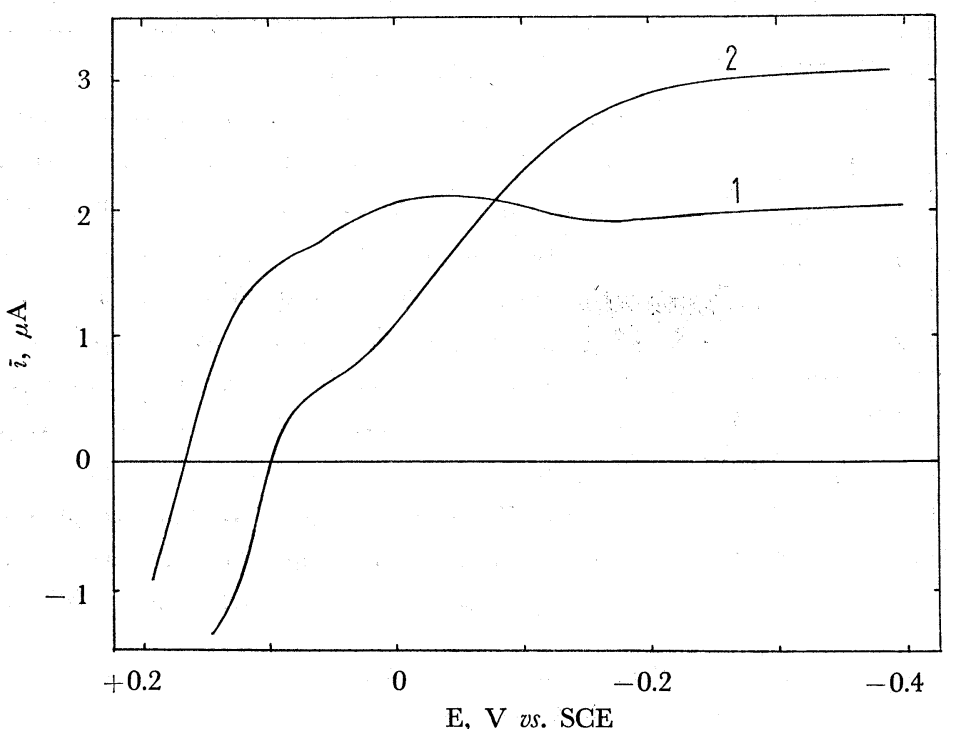

Fig. 2. Polarogram of approximately $0.6 \mathrm{~m} M\left[\mathrm{CoBr}\left(\mathrm{NH}_{3}\right)_{5}\right]\left(\mathrm{ClO}_{4}\right)_{2}$ in $0.9 M \mathrm{NaClO}_{4}+0.1 M$ acetate buffer (1) and that of 1.0 $\mathrm{m} M\left[\mathrm{Co}\left(\mathrm{H}_{2} \mathrm{O}\right)\left(\mathrm{NH}_{3}\right)_{5}\right]\left(\mathrm{ClO}_{4}\right)_{3}$ in $0.9 M \mathrm{NaClO}_{4}+0.1 M$ acetate buffer $+4 \times 10^{-4} M \mathrm{NaBr}$ (2). The residual current is not corrected.

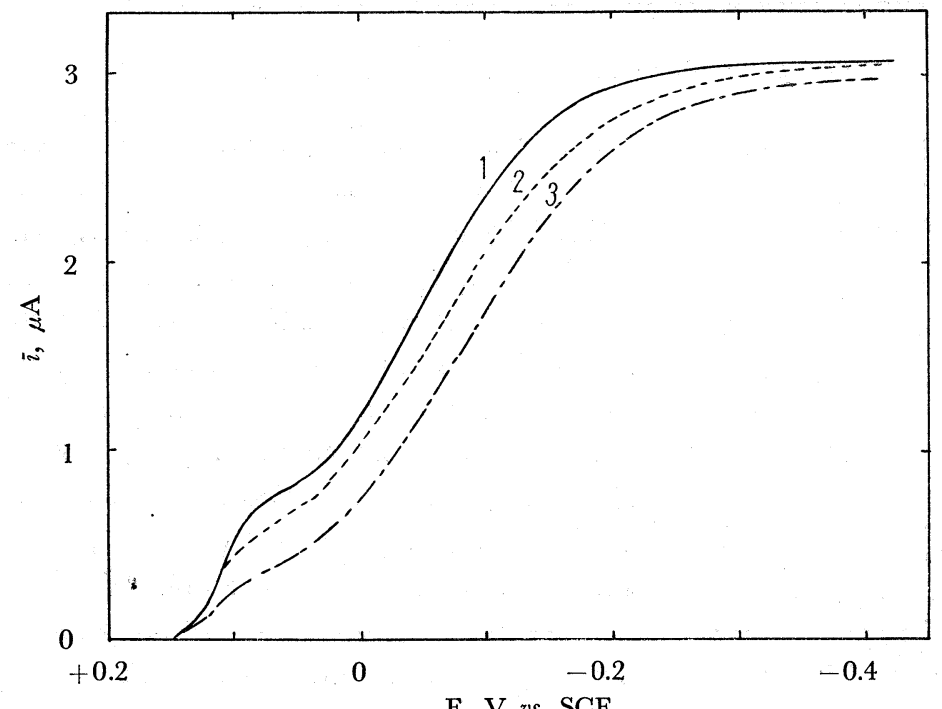

Fig. 3. Polarograms of $1.0 \mathrm{mM}\left[\mathrm{Co}\left(\mathrm{H}_{2} \mathrm{O}\right)\left(\mathrm{NH}_{3}\right)_{5}\right]\left(\mathrm{ClO}_{4}\right)_{3}$ obtained in the solutions containing $0.9 M \mathrm{NaClO}_{4}, 0.1 M$ acetate buffer and $4 \times 10^{-4} M \mathrm{NaBr}$ in the absence (1) and the presence of $2 \times 10^{-5}$ $M$ LEO (2) and $0.01 \%$ gelatin (3). Corrected for the residual current. 


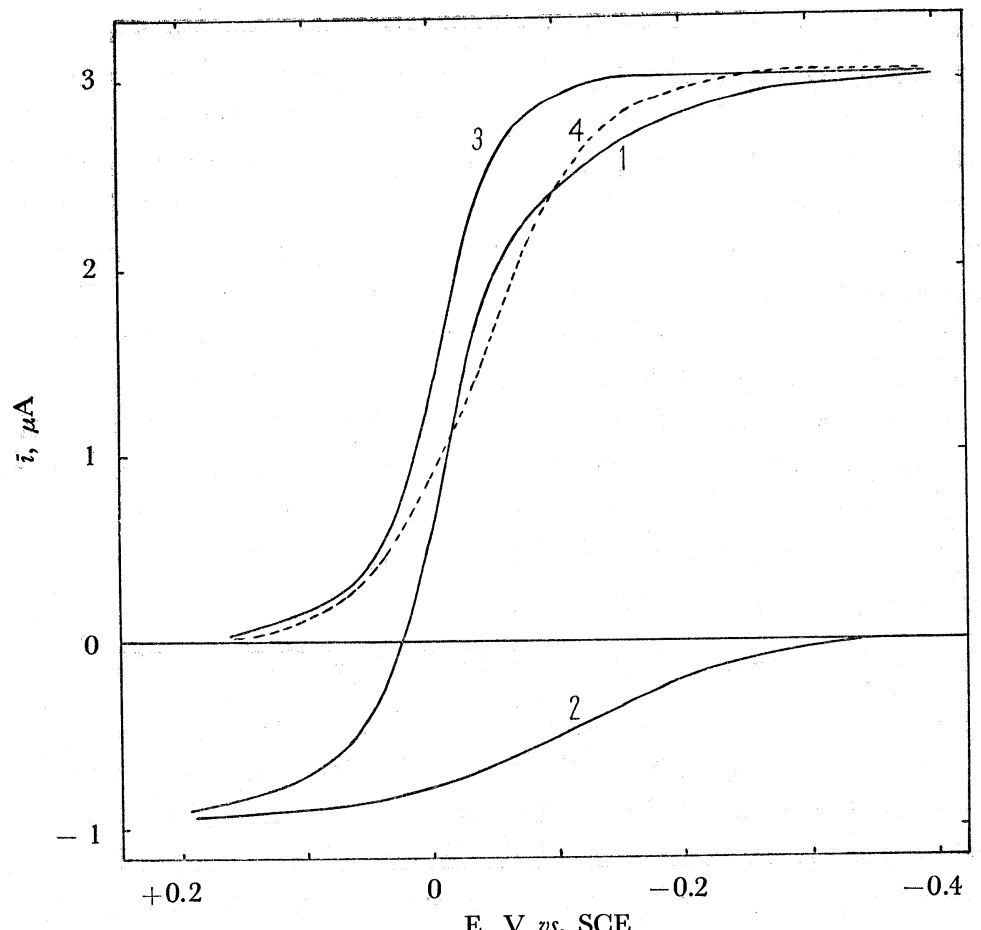

$\mathrm{E}, \mathrm{V}$ vs. SGE

Fig. 4. Polarograms of $1.0 \mathrm{~m} M\left[\mathrm{Co}\left(\mathrm{H}_{2} \mathrm{O}\right)\left(\mathrm{NH}_{3}\right)_{5}\right]\left(\mathrm{ClO}_{4}\right)_{3}$ obtained in the solutions containing $0.9 M \mathrm{NaClO}_{4}$ and $0.1 M$ acetate buffer with (1) and without (4) $2 \times 10^{-4} M$ NaI. Curve 2 is a polarogram of $2 \times 10^{-4} M \mathrm{NaI}$ in $0.9 \mathrm{M} \mathrm{NaClO}_{4}$ and $0.1 M$ acetate buffer, and curve 3 is obtained by subtracting curve 2 from curve 1 .

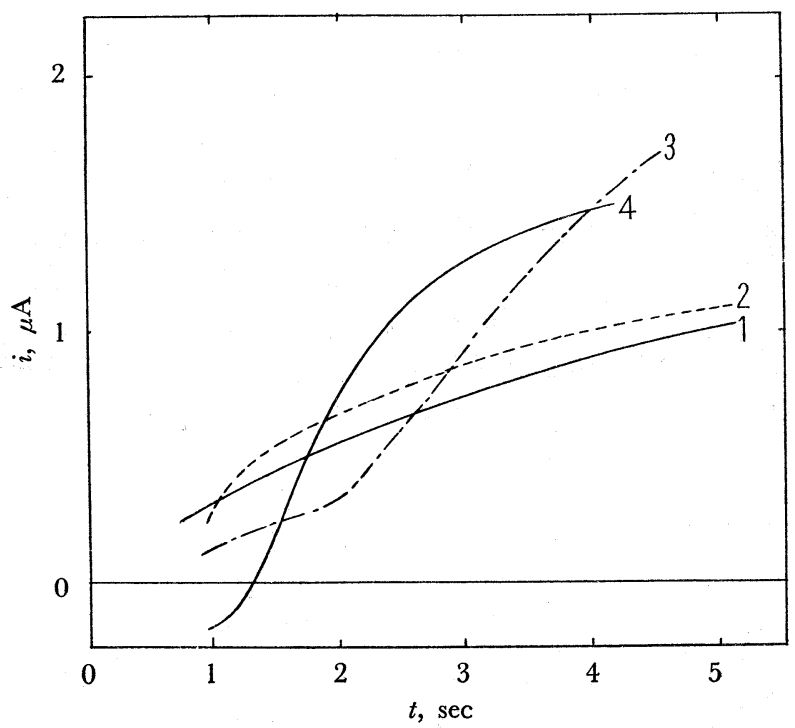

Fig. 5. Gurrent-time curves of $1.0 \mathrm{mM}\left[\mathrm{Co}\left(\mathrm{H}_{2} \mathrm{O}\right)\left(\mathrm{NH}_{3}\right)_{5}\right]$ $\left(\mathrm{ClO}_{4}\right)_{3}$ obtained at $0 \mathrm{~V}$ vs. SCE in the solutions containing $0.9 \mathrm{M} \mathrm{NaClO}_{4}$ and $0.1 M$ acetate buffer in the absence (1) and the presence of $1 \times 10^{-4} M$ $(2), 2 \times 10^{-4} M(3)$ and $3 \times 10^{-4} M(4) \mathrm{NaI}$. Not corrected for the residual current. 
curve 1 gives a reduction current at potentials more positive than the reduction wave of aquopentamminecobalt(III) ions (curve 4). The slope of log-plot analysis of curve 4 is 105 $\mathrm{mV}$, whereas that of curve 3 is $60 \mathrm{mV}$, which agrees with the theoretical value for the reversible one-electron reduction. In Fig. 5 are shown the $i-t$ curves measured at $0 \mathrm{~V}$ at various iodide concentrations. A remarkable change in the $i-t$ curve with the lapse of time was observed. The change of its appearance with the lapse of time was analogous to the one that was observed when the iodide concentration becomes smaller. When a polarogram was not recorded, the circuit was open, but mercury was being dropped from the electrode. The surface of mercury at the bottom of the electrolysis cell was covered with a yellow film, which was considered to be mercurous iodide. A deaerated solution of 0.9 $M$ sodium perchlorate and $0.1 M$ acetate buffer containing $0.5 \mathrm{~m} M$ of the complex and 0.5 $\mathrm{m} M$ of sodium iodide was stirred in contact with mercury for an hour by a magnetic stirrer; mercury was added to the solution after dissolved oxygen had been removed by bubbling nitrogen gas so that the reaction ${ }^{5}$,

$$
\mathrm{Hg}+\mathrm{I}^{-}+\frac{1}{2} \mathrm{O}_{2}+\mathrm{H}_{2} \mathrm{O} \rightleftharpoons \frac{1}{2} \mathrm{Hg}_{2} \mathrm{I}_{2}+\frac{1}{2} \mathrm{H}_{2} \mathrm{O}_{2}+\mathrm{OH}^{-}
$$

would not have taken place. A polarogram of the solution treated with mercury showed only a reduction wave from $\mathrm{Co}(\mathrm{II})$ to $\mathrm{Co}(0)$ at $-1.25 \mathrm{~V}$, indicating that the iodide and the cobalt(III) complex ions in the solution had been consumed. However, the polarogram of the solution containing only the cobalt(III) complex or iodide ions showed no change before and after stirring in contact with mercury. This observation suggests that mercury is oxidized to produce mercurous iodide only when both the cobalt(III) complex and iodide ions exist together, and consequently the concentrations of iodide and cobalt (III) complex ions decrease, namely, the reaction,

$$
\begin{aligned}
{\left[\mathrm{Co}\left(\mathrm{H}_{2} \mathrm{O}\right)\left(\mathrm{NH}_{3}\right)_{5}\right]^{3+} } & +\mathrm{Hg}+\mathrm{I}^{-}+n \mathrm{H}_{3} \mathrm{O}^{+} \\
& \rightleftharpoons\left[\mathrm{Co}\left(\mathrm{H}_{2} \mathrm{O}\right)_{n+1}\left(\mathrm{NH}_{3}\right)_{5-n}\right]^{2+}+\frac{1}{2} \mathrm{Hg}_{2} \mathrm{I}_{2}+n \mathrm{NH}_{4}^{+}
\end{aligned}
$$

seems to occur. Yalman ${ }^{6}$ reported that aquopentamminecobalt(III) ion is decomposed in the presence of iodide ion to produce $\mathrm{Co}(\mathrm{II})$ ion and iodine according to the equation,

$$
\left[\mathrm{Co}\left(\mathrm{H}_{2} \mathrm{O}\right)\left(\mathrm{NH}_{3}\right)_{5}\right]^{3+}+\mathrm{I}^{-}+n \mathrm{H}_{3} \mathrm{O}^{+} \rightleftharpoons\left[\mathrm{Co}\left(\mathrm{H}_{2} \mathrm{O}\right)_{n+1}\left(\mathrm{NH}_{3}\right)_{5-n}\right]^{2+}+\frac{1}{2} \mathrm{I}_{2}+n \mathrm{NH}_{4}^{+}
$$

In this experiment, however, reaction (4) did not proceed within a few hours; the concentration of cobalt(III) was the same and no iodine was detected by the starch reaction.

Table 4. Standard Potentials and Equilibrium Constants for Reaction $\left(3^{\prime}\right)$.

\begin{tabular}{c|c|c}
\hline $\begin{array}{c}\text { halide } \\
\text { ion, } \mathrm{X}^{-}\end{array}$ & $E^{\circ}, \mathrm{V}$ & $K$ \\
\hline $\mathrm{I}^{-}$ & +0.3705 & $1.81 \times 10^{6}$ \\
$\mathrm{Br}^{-}$ & +0.1903 & $1.64 \times 10^{3}$ \\
$\mathrm{Cl}^{-}$ & +0.0624 & $1.13 \times 10$ \\
\hline
\end{tabular}

The cobalt(III) complex ions were also reduced by mercury in the presence of bromide ions, but the reaction proceeded only by about $40 \%$ after the solution containing $0.5 \mathrm{mM}$ of the complex and $0.5 \mathrm{mM}$ of bromide ions was stirred in contact with mercury for two hours. As shown in Table 4, the incomplete reduction of the cobalt(III) complex in the presence of bromide ions is due to a smaller standard electromotive force or equilibrium constant of reaction (3) for bromide than

iodide. The values cited in Table 4 were calculated for the reaction,

$$
\left[\mathrm{Co}\left(\mathrm{H}_{2} \mathrm{O}\right)\left(\mathrm{NH}_{3}\right)_{5}\right]^{3+}+\mathrm{Hg}+\mathrm{X}^{-} \rightleftharpoons\left[\mathrm{Co}\left(\mathrm{H}_{2} \mathrm{O}\right)\left(\mathrm{NH}_{3}\right)_{5}\right]^{2+}+\frac{1}{2} \mathrm{Hg}_{2} \mathrm{X}_{2}
$$

by using the formal oxidation potential ${ }^{7}$ measured in $1 M$ of ammonium perchlorate for the reaction, 


$$
\left[\mathrm{Co}\left(\mathrm{H}_{2} \mathrm{O}\right)\left(\mathrm{NH}_{3}\right)_{5}\right]^{2+} \rightleftharpoons\left[\mathrm{Co}\left(\mathrm{H}_{2} \mathrm{O}\right)\left(\mathrm{NH}_{3}\right)_{5}\right]^{3+}+\mathrm{e}, \quad E^{0}=-0.33 \mathrm{~V}
$$

and the standard oxidation potential ${ }^{8)}$ for the reaction,

$$
\mathrm{Hg}+\mathrm{X}^{-} \rightleftharpoons \frac{1}{2} \mathrm{Hg}_{2} \mathrm{X}_{2}+\mathrm{e}
$$

where $\mathrm{X}^{-}$means halide ions.

In contrast with the cobalt(III) complex, the aquopentamminechromium(III) complex ion gave no prewave in the presence of bromide ions. When a large concentration of iodide ions was added to the solution, no prewave was observed, but the whole reduction wave shifted to less negative potentials (see Fig. 6). Since the reduction of iodopentammine-

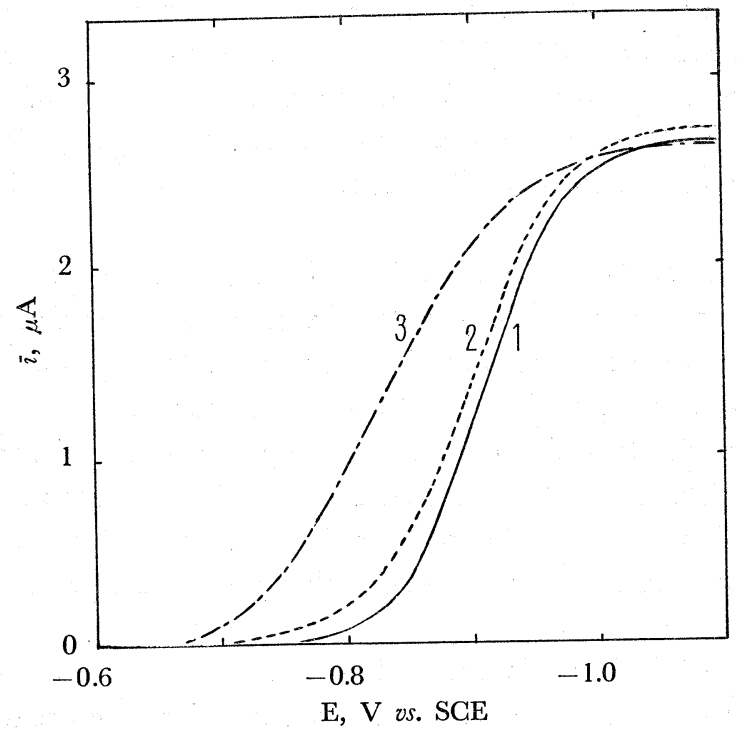

Fig. 6. Polarograms of $1.0 \mathrm{~m} M\left[\mathrm{Cr}\left(\mathrm{H}_{2} \mathrm{O}\right)\left(\mathrm{NH}_{3}\right)_{5}\right]-$ $\left(\mathrm{ClO}_{4}\right)_{3}$ obtained in the solutions containing $0.9 \mathrm{M} \mathrm{NaClO}_{4}$ and $0.1 M$ acetate buffer in the absence (1) and the presence of $0.016 M$ $\mathrm{NaI}(2)$ and that obtained in the solution containing $0.7 M \mathrm{NaClO}_{4}, 0.1 \mathrm{M}$ acetate buffer and $0.2 M \mathrm{NaI}$ (3). Corrected for the residual current.

chromium(III) ions at the DME takes place at more positive potentials, the curve 3 in Fig. 6 would not be thereduction wave of iodopentamminechromium(III) ions.

\section{Discussion}

According to Vlček ${ }^{1)}$ the complex ions like $\left[\mathrm{CoY}\left(\mathrm{NH}_{3}\right)_{5}\right]^{2,3+}$ are oriented in such a way that the group $\mathrm{Y}$ is as apart as possible from the electrode surface, and this orientation is convenient for the substitution reaction, the heterogroup being accessible for the exchange with other ligands without any bond breaking and rearrangement of the complex. $\mathrm{He}$ also mentioned that, when the complex like $\left[\mathrm{CoX}\left(\mathrm{NH}_{3}\right)_{5}\right]^{2+}$ is reduced at the DME, where $\mathrm{X}$ is $\mathrm{Cl}^{-}, \mathrm{Br}^{-}, \mathrm{I}^{-}$, or $\mathrm{SCN}^{-}$which has a strong affinity to mercury, the heteroligand $\mathrm{X}$ is oriented to the $\mathrm{DME}^{9}$. If the substitution reaction (1) and the electron-transfer reaction proceed at the electrode according to the mechanism explained above, the halopentamminecobalt(III) complex ion formed at the electrode surface must be inverted and direct 
the heterolignad $\mathrm{X}$ to the electrode surface to accept an electron. This process seems to require a greater activation energy.

As the surface of mercury is positively charged, iodide or bromide anions will be adsorbed on the mercury surface and the oxidation-reduction reaction (3) will proceed at the mercury surface; one electron transfers from mercury to the complex ion, when a halide ion will act the role of a bridge between mercury and the complex ion. The mercurous cation thus produced reacts at once with halide ion to form mercurous halide. The situation will be the same as the one in the case of the electrode reaction at the DME in the presence of halide ions. Kuta ${ }^{10}$ ) reported that the substitution reaction (1) at the surface of the electrode is the most rapid in the case of iodide present. Since the reduction potential of iodopentamminecobalt(III) is more positive than that of aquopentamminecobalt(III) and the concentration of iodide ion is smaller than that of aquopentamminecobalt(III), a prewave due to the reduction of iodopentamminecobalt(III) ion must be observed if the substitution reaction is rapid. Such a prewave, however, does not appear, as shown in Fig. 4.

The reduction of aquopentamminechromium(III) ion gives no prewave in the presence of halide ions. As the chromium(III) complex is in general more substitution-labile than the cobalt(III) complex, the prewave would be expected to appear, if the prewave is kinetically controlled according to the substitution reaction (1).

From all the results mentioned above, it is more probable to think that the prewave which is kinetic in nature is not the reduction wave of halopentamminecobalt(III) ion formed by the substitution reaction (1), but the reduction wave of mercurous halide formed by the oxidation-reduction reaction (3) which takes place at the surface of the electrode. The reason why the prewave does not appear in the case of iodide ion may be considered as follows; the curve 1 or 3 in Fig. 4 is a mixed current which consists of the reduction of aquopentamminecobalt(III) ion and that of mercurous iodide produced by the reaction (3). Because of almost the same reduction potentials of both the complex and mercurous iodide, no prewave is observed. In Fig. 4, curve 3 which is drawn by subtracting curve 2 from curve 1 is steeper than curve 4. This is because the current corresponding to the reduction of mercurous iodide is added in the case of curve 3. Although the slope of the $\log$-plot analysis of curve 3 is $60 \mathrm{mV}$, which is expected for a one-electron reversible type, the current around the half-wave potential is independent of the height of mercury reservoir. This indicates that the electrode process is not of a simple diffusion-controlled type around the half wave potential, but of a more involved one. As shown in Fig. 5, the $i-t$ curve also shows a peculiar shape. If the $i-t$ curve around the half-wave potential is of a diffusion-controlled type, the current should be proportional to $t^{1 / 6}$.

Fig. 7 shows anodic dissolution waves of the anions and the reduction wave of aquopentamminecobalt(III) ion. In the narrow region of potentials at the foot of the polarogram of the aquopentamminecobalt(III) complex, the following four reactions take place in the presence of halide or thiocyanate ions;

a) anodic dissolution of mercury,

$$
\mathrm{Hg}+\mathrm{X}^{-} \rightleftharpoons \frac{1}{2} \mathrm{Hg}_{2} \mathrm{X}_{2}+\mathrm{e}
$$

b ) the oxidation-reduction reaction expressed by the equation,

$$
\begin{aligned}
{\left[\mathrm{Co}\left(\mathrm{H}_{2} \mathrm{O}\right)\left(\mathrm{NH}_{3}\right)_{5}\right]^{3+} } & +\mathrm{Hg}+\mathrm{X}^{-}+n \mathrm{H}_{3} \mathrm{O}^{+} \\
& =\left[\mathrm{Co}\left(\mathrm{H}_{2} \mathrm{O}\right)_{n+1}\left(\mathrm{NH}_{3}\right)_{5-n}\right]^{2+}+\frac{1}{2} \mathrm{Hg}_{2} \mathrm{X}_{2}+n \mathrm{NH}_{4}^{+}
\end{aligned}
$$




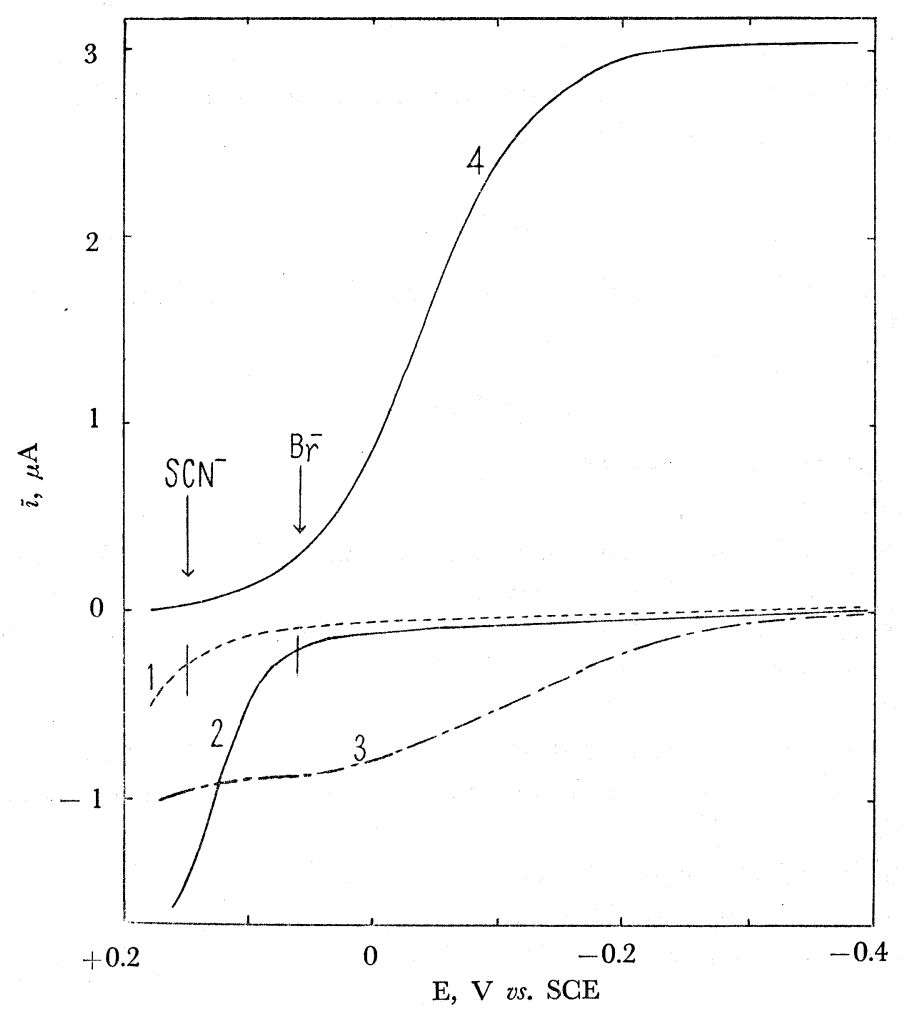

Fig. 7. Current-potential curves of $5 \times 10^{-4} M \mathrm{KSCN}(1)$, $4 \times 10^{-4} M \mathrm{NaBr}(2), 2 \times 10^{-4} M \mathrm{NaI}(3)$ and $1.0 \mathrm{mM}$ $\left[\mathrm{Co}\left(\mathrm{H}_{2} \mathrm{O}\right)\left(\mathrm{NH}_{3}\right)_{5}\right]\left(\mathrm{ClO}_{4}\right)_{3}$ (4) obtained in the solutions containing $0.9 \mathrm{M} \mathrm{NaClO}_{4}$ and $0.1 M$ acetate buffer. Arrows show the potentials where prewaves appear in the presence of the anions indicated.

which proceeds even at open circuit,

c) the reduction of mercurous halide formed in process (b),

$$
\frac{1}{2} \mathrm{Hg}_{2} \mathrm{X}_{2}+\mathrm{e} \rightleftharpoons \mathrm{Hg}+\mathrm{X}^{+}
$$

d) the reduction of the aquopentamminecobalt(III) ion,

$$
\left[\mathrm{Co}\left(\mathrm{H}_{2} \mathrm{O}\right)\left(\mathrm{NH}_{3}\right)_{5}\right]^{3+}+n \mathrm{H}_{3} \mathrm{O}^{+}+\mathrm{e} \longrightarrow\left[\mathrm{Co}\left(\mathrm{H}_{2} \mathrm{O}\right)_{n+1}\left(\mathrm{NH}_{3}\right)_{5-n}\right]^{2+}+n \mathrm{NH}_{4}^{+}
$$

In the presence of bromide, a prewave is observed because of the different reduction potentials of mercurous bromide formed by reaction (3) and the complex ion.

The reason why the aquopentamminechromium(III) ion does not give a prewave in the presence of halide ions is that since the reduction potential of the chromium(III) complex is more negative than the oxidation-reduction potential of the couple of mercury and mercurous halide, an oxidation-reduction reaction of the type of Eq. (3) can not occur, and consequently mercurous halide is not formed at the DME.

The fact that the presence of a large concentration of iodide ions shifts the reduction potential of aquopentamminechromium(III) ion to less negative potentials is considered to be due to the specific adsorption of iodide ions to the DME (see Fig. 6). The specific adsorption of iodide changes the structure of the double layer and increases the negative 
charge at the electrode surface. Consequently, the complex cation will approach to the electrode more easily. The reason why the shape of the c-v curve is not a reversible type seems due to the gradual decrease in the quantity of the specific adsorption of iodide ions with increasing negative potentials. ${ }^{11,12)}$

\section{Acknowledgement}

The authors wish to thank the Ministry of Education for the financial support granted for this research.

\section{References}

1) A.A. Vlček and J. Kůta, Nature, 185, 95 (1960).

2) A. Werner, Ber., 40, 4104 (1907).

3) N. Tanaka, Y. Sato, R. Tamamushi and G. Satô, Bull. chem. Soc. Japan, 36, 1059 (1963).

4) A.A. Vlečk, Collection Czechosloo. Chem. Communs., 24, 3538 (1959).

5) I.M. Kolthoff and J.J. Lingane, "Polarography", Vol. 1, Interscience Publishers, (1946), p. 397.

6) R.G. Yalman, J. Am. Chem. Soc., 75, 1842 (1953).

7) R.G. Yalman, Inorg. Chem., 1, 16 (1962).

8) W.M. Latimer, "Oxidation Potentials", 2nd edition, Prentice Hall, N.Y. (1952), p. 175.

9) A.A. Vlček, "Progress in Inorganic Chemistry", Vol. 5, ed. by F.A. Cotton, Interscience Publishers, (1963), p. 345.

10) J. Kůta, Reviewe of Polarography (Japan), 11, 62 (1963).

11) D.C. Grahame, J. Am. Chem. Soc., 80, 4201 (1958).

12) D.C. Grahame and R. Parsons, ibid., 83, 1291 (1961).

滴下水銀電極に特けるアコペンタアンミンコバルト (III)

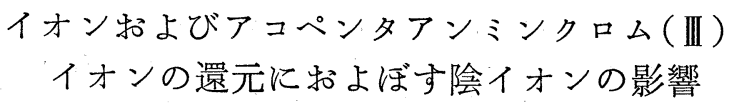

田中 信行, 佐藤 祐一, 玉虫 伶太

(東北大学理学部化学教室)

滴下水銀電極におけるアコペンタアンミンコバルト (III) イオンおよびアコペンタアンミンクロム (III) イオ ンの還元におよぼすハロゲンイオン，チオシアン酸イ オンの影響を直流ポーラログラム, 電流時間曲線を記 録するてとによって検討した。コバルト（III) 錯イオン の場合，臭素イオン，塩素イオン，チオシアン酸イオ

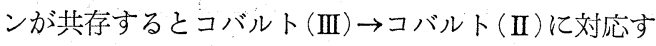
る還元波より正の電位に水銀の溶出波に引き続いて反
応電流の性質を持った前波が現われる。しかし、ヨウ 素イオンの共存では前波は現われない. クロム(III) 錯 イオンの場合上記陰イオンによって前波は現われず, 多量のヨウ素イオンを添加したときクロム (III) $\rightarrow$ ク ム（II）の還元波全体がより正の電位に移行した。これ らの挙動の違いを錯イオンの酸化還元電位と水銀一八 ロゲン 化水銀 $(I)$ 系の 酸化還元電位の 差から 説明し た. 